\title{
Socio-economics of Acai Production in Rural Communities in the Brazilian Amazon: A Case Study in the Municipality of Igarapé-Miri, State of Pará
}

\author{
José Itabirici de Souza e Silva Junior ${ }^{1}$, Fabrício Khoury Rebello ${ }^{1}$, Herdjania Veras de Lima ${ }^{1}$, \\ Marcos Antônio Souza dos Santos ${ }^{1}$, Paola Corrêa dos Santos ${ }^{1} \&$ Maria Lúcia Bahia Lopes ${ }^{2}$ \\ ${ }^{1}$ Universidade Federal Rural da Amazônia, Belém, Pará, Brazil \\ ${ }^{2}$ Universidade da Amazônia, Belém, Pará, Brazil \\ Corresponding author: Fabrício Khoury Rebello, Agronomy Graduation Program, Universidade Federal Rural da \\ Amazônia, Belém, Pará, Brazil. E-mail: fabriciorebello@hotmail.com
}

Received: January 5, 2019

doi: $10.5539 /$ jas.v11n 5 p215

\begin{abstract}
The Acai, a fruit of the Acai tree (Euterpe oleracea Mart.), is one of the main foods consumed by the riverside communities in the Brazilian Amazon. In addition, it has become the main source of income of these small producers as its consumption has widely expanded since the 1990s due to the recognition of its properties as an energetic and functional food. In order to analyze the production system and the socioeconomic changes that occurred in rural communities whose economical support is from the management of the Acai tree, a case study was carried out in two communities on the island of Mamangal, in the municipality of Igarapé-Miri, in the state of Pará, Brazilian Amazon. Fifty-two semistructured questionnaires were applied to the Acai farming families in these communities located in the municipality in the largest Brazilian producer of this fruit. The main transformations observed in the assessed communities, especially since the last decade, were influenced by the access to electric energy and the expansion of income from the Acai that made possible the expansion of the acquisition of durable consumer goods that even contributed to diversifying the diet of those farmers. Some of the difficulties faced by Acai production are the lack of technical assistance and rural extension services as well in addition to the strong dependence of the communities on the income generated by the Acai.
\end{abstract}

Keywords: Euterpe oleracea Mart., family farming, rural development, plant extractivism

\section{Introduction}

Acai (Euterpe oleracea Mart.) is a palm native to the Amazonian estuary, with a prominence among the several vegetal biological resources due to its abundance and for being an important source of food for local populations (Rebello, 1992; Nogueira \& Homma, 1998). Its fruit is rounded, of dark-violet color when ripe, with about 1 to $1.5 \mathrm{~cm}$ in diameter and mesocarp of $1 \mathrm{~mm}$ of thickness (Cavalcante, 2010).

From the mechanical maceration of the fruit pulp a viscous liquid is produced rich in anthocyanins (ACNs), proanthocyanidins (PACs) and other flavonoids (Schauss et al., 2006, Cavalcante, 2010), widely used in the production of pulp, ice creams, sweets, jams, and juices. Locally, this "wine" (juice) is produced in small agroindustry plants for commercialization in the urban areas, being able to present three consistencies (fine, medium and coarse). In the riverside communities, in general, it is processed by the rural producers themselves, constituting the basis of food security for these traditional and low-income populations (Note 1).

In the 1990s, the discovery of its high energy value and the fashion of its consumption in fitness centers had increased the search for the product, resulting in a significant commercial value in many Brazilian states in addition to an international interest (Costa et al., 2017). Furthermore, the antioxidant properties of anthocyanin, which is capable of preventing the oxidation of LDL cholesterol and cardiovascular diseases, among others (Schauss et al., 2006; Udani et al., 2011) and its use by the industry of cosmetics that started to use its benefits to launch several products such as anti-aging creams and wide bath line from the Acai oil, has intensified the interest of small producers in increasing the production of the fruit. 
Therefore, management of native Acai crops began in the Brazilian Amazon about three decades ago and it did not go far to the time when the entire supply of Acai was extractive and came from the islands surrounding Belém, the capital of the state of Pará, Brazil, a leading consumer center.

The state of Pará is the largest Brazilian producer of Acai, holding $95.47 \%$ in Brazilian production. The municipality of Igarapé-Miri, in turn, is the largest Brazilian producer, accounting for $21.00 \%$ of the country's production and $21.27 \%$ of Para's production, with 280 thousand tons of fruit per year, according to data of the Brazilian Institute of Geography and Statistics (IBGE, 2018b), thus justifying the locus of this research.

By considering the demand pressure that the Acai has been suffering, and the great price oscillations resulting from that and the off-season periods, it is important to analyze the socioeconomic impacts that the production of Acai has been causing in the regional communities, especially in the island of Mamangal, which stands out as one of the production areas in the municipality of Igarapé-Miri. Thus, this article evaluated the socioeconomic structure of the Acai producing families to verify the social, economic and environmental impacts that are occurring in the producing communities as a result of intensification in the production in the studied area and the possible risks imposed to them by it.

\section{Methodology}

\subsection{Study Area}

The municipality of Igarapé-Miri is located in the mesoregion of Northeastern Pará, about $89 \mathrm{~km}$ from Belém, capital of the state of Pará (PA), in the Brazilian Amazon. It has an estimated population of 62.35 thousand inhabitants and a territorial area of $1,996,790 \mathrm{~km}^{2}$ (IBGE, 2018a). The climate of the municipality corresponds to the macro thermal, type Am according to the classification of Köppen, corresponding to the hot and humid equatorial, propitious for production and development of the Acai trees.

The present study was carried out in two communities in Mamangal Island, in the municipality of Igarapé-Miri (PA), located at the confluence and border of the Maiuaitá with the Meruú rivers, with the following geographic coordinates: $01^{\circ} 58^{\prime} 30^{\prime \prime} \mathrm{S}$ and $48^{\circ} 57^{\prime} 36^{\prime \prime} \mathrm{W}$. The island's population is about 1,817 inhabitants, consisting of 442 families living in six communities spread over a land area of $26 \mathrm{~km}^{2}$ (INCRA, 2006). The main via of access from the municipality's headquarters is the fluvial network, with a route covered in about 1:30 hours of travel. The displacement is carried out mainly in small boats or in rabetas, canoes with a small gasoline engine coupled to their stern.

The two communities visited in this study were Mamangal Grande and Mamangalzinho, the most representative in population and in the production of Acai, with about 191 families during the study.

It is interesting to note that in the feasibility study for the implementation of an Agro-Extractive Settlement Project (PAE) in the island of Mamangal, conducted by the Instituto Nacional de Colonização e Reforma Agrária (INCRA, 2006) - National Institute of Colonization and Agrarian Reform - the living conditions in the locality were considered as precarious and requiring the intervention of the public authorities.

\subsection{Survey and Data Analysis}

The field research was carried out in january 2017, involving the application of semi-structured questionnaires contemplating questions about general conditions of farmers and their families (schooling, number of children, feeding, access to durable consumer goods, among others), infrastructure and basic sanitation (household conditions and local availability of sanitation - water, sewage and garbage collection), sources of income, access to credit and technical assistance, conditions of management and production of Acai. Fifty-two questionnaires were applied, which was equivalent to $27.23 \%$ of the families living in the two assessed communities.

In addition, the Cross-Walk method was applied and carried out in the set of visited farms (52). The method consists in covering the area by means of visits to the different plots of the production system, accompanied by the farmer, observing and collecting information on the adopted technologies, local practices of Acai management and commercialization, contributing to the triangulation with the collected data through the interviews (questionnaires).

The sample was non-probabilistic by trial, based on the personal evaluation of the researcher, which invites the interviewees to participate in the research which results in building a network of interlocutors.

Sample was selected by using the Snowball technique, since this technique allows the interviewee to indicate the next interviewee, thus unraveling the network of inter-relationships established around the issue.

The collected data were tabulated in Microsoft Excel and analyzed by means of Statistic Package for Social Sciences (SPSS) version 22.0, all in a Windows 7. 


\section{Results and Discussion}

\subsection{Socioeconomic Characterization of the Farmers}

The communities visited on the island of Mamangal dedicate themselves to the production of Acai by using the system of management of native Acai areas in small farms. Figure 1 shows aspects of fruit (1A), Acai tree (1B) and housing conditions in the evaluated communities (1C and 1D).

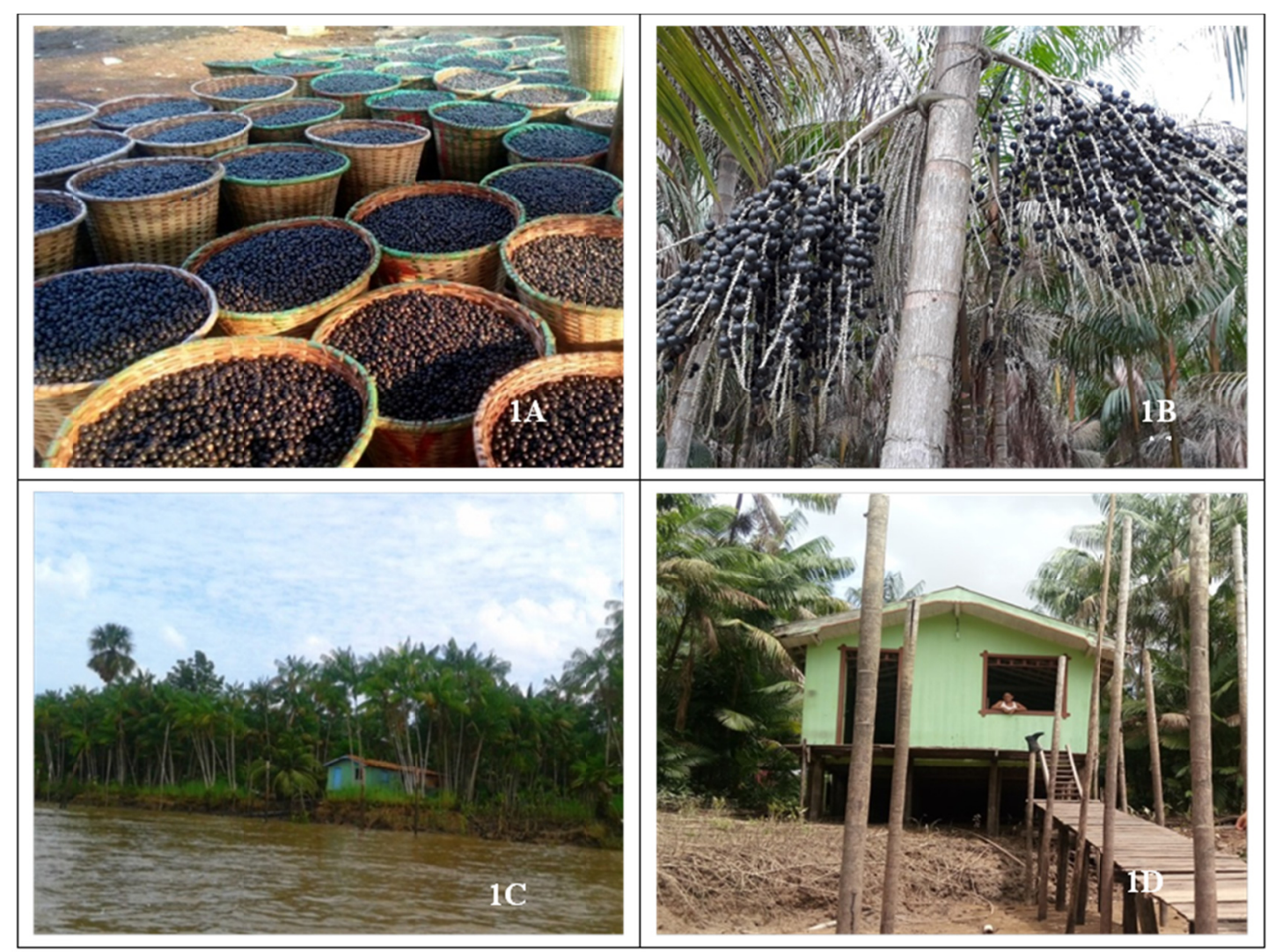

Figure 1. Aspects of the fruit, Acai tree, and households on Mamangal island, Brazilian Amazon

Source: Silva Júnior (1A, 1C and 1D); Rebello (1B).

Acai producers in the studied communities are 46 years old, on average, varying between 22 and 88 years old, where $50 \%$ are over 40 years old (Table 1). This data shows that the participation of adults and the elderly in the production of Acai is still representative. The average residence time in the rural property is 30 years, with 92.3\% declaring that they have always lived in the rural area, demonstrating, in this way, that these families have significant knowledge about the area, as well as mastering of extractive practices and, more recently, the management of native Acai trees. 
Table 1. Distribution of the dwellers in the communities visited on Mamangal island, in Igarapé-Miri municipality, according to the following variables: age, number of children, housing, income, loan, and Acai production

\begin{tabular}{lllll}
\hline Variable & Average & Med. & Min. & Max. \\
\hline Age & 46.37 & 40.5 & 22 & 88 \\
Number of children & 3.65 & 3 & 0 & 12 \\
Number of people in the household & 3.98 & 4 & 2 & 9 \\
Residence time (years) & 29.67 & 24.5 & 2 & 72 \\
Number of rooms in the house & 3.1 & 3 & 1 & 8 \\
Monthly income with Acai (harvest) (R\$) & $1,245.76$ & $1,000.00$ & 300.00 & $3,000.00$ \\
Other incomes (R\$) & 633.30 & 768.50 & 124.00 & $1,200.00$ \\
Loan (R\$) & $7,127.27$ & $6,500.00$ & $1,500.00$ & $15,000.00$ \\
\hline
\end{tabular}

Note. Med. = Median; Min. = Minimum; Max. = Maximum.

In relation to the number of children, the average was four children per family. Such data coincide with the results obtained by Rodrigues et al. (2017) in a study carried out in a traditional rural community in the state of Pará. This average number of children is part of a new family configuration within communities, a reflection of the social dynamics that reduces the number of children per family.

Regarding the schooling of the interviewees, $42.3 \%$ studied until the $4^{\text {th }}$ grade of the primary school, $17.3 \%$ are studying the in the initial series $\left(1^{\text {st }}\right.$ to $4^{\text {th }}$ grade of the primary school), $11.5 \%$ have completed the $5^{\text {th }}$ to $8^{\text {th }}$ grade of basic schooling 2 and $1.9 \%$ are high school graduated. The illiterates are $5.8 \%$ and the other $21.2 \%$ consider themselves literate. From this information, it can be inferred that the level of schooling of producers is low, requiring special attention regarding the transfer of technical guidelines for the implementation of innovative and more sustainable agricultural practices, the adoption of articulated forms of cooperation among these farmers, phytosanitary improvements and product quality (Acai and heart palm), farm management and marketing of production. The expansion of knowledge is an important issue in the area of study. Thus, initiatives that value human, social and institutional capital are extremely relevant to enhance the search for more sustainable development in the Amazon (Rebello \& Homma, 2017).

The average income of these producers achieved with the commercialization of Acai is around R\$ 1,245.76 per month in the harvest period, which in comparison to the results found by Rodrigues et al. (2017), who indicated an average income for Acai producers in the Marajó region around 339.48/month, represents a value 3.67 times higher. This result allows inferring that the production of Acai in Igarapé-Miri has a relevant weight in the income of these families, especially when it is considered that $75 \%$ of the families do not have access to any type of benefit of government assistance programs and that only $15 \%$ have a retirement pension.

About $19.23 \%$ of the residents reported having other sources of productive income unrelated to the production of Acai. This income is, on average, $\mathrm{R} \$ 633.30$ per month. Among these sources of income are the activities of artisanal fishing, heart palm extraction, carpentry, mechanics and catering services, mainly performed during the Acai off-season, when the fruit is scarcer and cannot meet the economic needs of families. Thus, this share of residents (19.23\%) seeks alternative income.

\subsection{Infrastructure and Basic Sanitation}

All interviewees had their own home, acquired by inheritance for most of them (51.9\%). The houses are mostly made of wood (78.8\%), 19.2\% are mixed (wood and masonry) and $2.0 \%$ are masonry, with an average size of $24.65 \mathrm{~m}^{2}$, with about three rooms per household. All of them are covered with ceramic tiles.

The preference for wood houses is due to the availability of raw material in the forest and the functionality of the houses, which are suspended by wooden supports due to the variation of tide height over the day (Nogueira, 2016). In addition, they suffer the influence of cultural aspects brought by the ancestors of flood forest dwellers (Celuppi et al., 2017). However, on the island of Mamangal, it can be noted that there is a portion (19.2\%) that already avoids these characteristics of dwellings, introducing concrete pillars to support the structure and cement floors coated in the tiles. These improvements, to a certain extent, were made from the income achieved with Acai.

Regarding the access to electric power, all households are already benefited by the power grid provided by Centrais Elétricas do Pará (CELPA), with 50\% have legal access to it and the other half have a clandestine access, 
since the company that provides the service has not yet expanded the wiring system to a part of the island. It should be noted that until the year 2006, residents of the community did not have electricity power (INCRA, 2006). At that time, some households had their own low-power generator and most households used kerosene lamps.

At the time of the survey, durable consumer goods in the households (Table 2) were examined as a way of inferring the quality of life and, eventually, to compare the evolution of this community with respect to income or future public policies that may have an impact on them.

Table 2. Availability of durable goods in the households of the interviewees on Malanga island in the municipality of Igarapé-Miri (PA)

\begin{tabular}{ll}
\hline Household Goods & Participation (\%) \\
\hline Television & 94.23 \\
Cell phone & 94.23 \\
Acai processing machine & 90.38 \\
Refrigerator & 86.54 \\
Radio & 40.38 \\
Freezer & 40.38 \\
Computer & 9.62 \\
Fan & 5.77 \\
Landline telephone & 3.85 \\
Washing machine & 1.92 \\
Drinker & 1.92 \\
\hline
\end{tabular}

Among the most prevalent goods were television $(94.23 \%)$, cell phone $(94.23 \%)$, Acai processing machine $(90.38 \%)$, refrigerator $(86.54 \%)$, radio $(40.38 \%)$, and freezer $(40.38 \%)$. Access to these goods demonstrates the transformation that the evaluated communities are experiencing with the arrival of electric power. The significant representativity of freezers in households is associated with the storage of foods such as meat, fish and chicken for consumption by the family, making this a kind of pantry since the market is very far from the community and the displacement is done by vessels that require the expenditure of time and financial expense with fuel, being very onerous and making the frequent trips to the market infeasible.

In the studied communities, $63.5 \%$ of the households dispose of sanitary waste is directly in the river. The others $(36.5 \%)$ had a sump. The river is also the main supplier of water for the various activities of daily life, as well as for consumption. As for consumption, $61.50 \%$ uses water directly from the river, $5.80 \%$ captures water which is basically treated with sodium hypochlorite. The $32.70 \%$ have a well to collect water for their basic consumption needs.

The island does not have a city garbage collection. So, communities seek other options to discard their solid waste. Among the options for waste disposal, $96.2 \%$ burn it in the backyards, $1.9 \%$ uses the composting process and the same value simply throws it in the yard. However, not all material can be burned, such as aluminum cans and glassware. These residues end up in the backyards and eventually end up being washed away by the tide. Thus, garbage is a major concern about the pollution of rivers, which has a direct impact on the island of Mamangal as it depends very much on this natural resource.

\subsection{Production System Analyses}

Acai is the main economic source of the inhabitants since $71.2 \%$ of the respondents depend exclusively on the income provided by the commercialization of this fruit during the harvest period.

Due to the great demand for Acai in the market, and because it is a native product of the flood forests besides being the main food of the communities, the small producers have adapted to the new management practices of the Acai tree to obtain greater production and, consequently, increase of income.

The management of Acai areas is done by $98.1 \%$ of the producers aiming at a better production of the fruits. The main management practices developed in the areas visited are the following: i) elimination of weeds and other invasive plants; and ii) thinning, which is the removal of the thinner, higher and less productive trunks leaving 3 to 4 producing trunks in the clump. However, $34.6 \%$ of the producers report that the greatest difficulty found in 
the community is the lack of financial resources to carry out the management and maintenance of the Acai areas. Another $15.4 \%$ reported finding difficulty with labor for the execution of management practices in areas with Acai trees.

According to Tagore et al. (2018), this management ends up in removing native species with significant damage to communities such as erosion, silting of the river and environmental imbalance. According to the same authors, these farmers have been adopting aggressive management practices that modify the natural landscape, compared to what was traditionally done, when the system was the Acai extractivism to supply the families' needs for self-consumption without income aggregation.

The harvest is made with the help of the peconha, a species of cord that can be made from Acai leaves or bags of flour. With the help of this resource, the peconheiro climbs on the tree and with the aid of a large knife, he or she cuts the bunch of Acai and returns to the ground. After the harvest, threshing of the Acai is carried out, wrapping it in rasas (Note 2), shallows, which is usually performed by the women.

The current management in the island of Mamangal has proved to be effective from the financial point of view since thinning provides another income, with the extraction of the palm heart besides reducing the competition of the trunks by nutrients and reduces the density of plants that can result in the erosion of the areas cropped with Acais, damaging the production, as well as causing accidents in the harvest.

The question that arises is about the environmental and economic sustainability of this system, since it is not able to meet the growth of market demand, as Homma (2014) warns when argues about the limits of the extractive system for products that present conflict between demand and supply, as is the current case of Acai. In addition, the intense thinning can cause environmental imbalance and loss of other resources of long-term interest to the communities.

The production is destined to self-consumption $(20 \%)$ and commercialization $(80 \%)$ to obtain income for the family. Although the producers are relatively close to the consumer market, they do not direct the product to the port of Igarapé-Miri because they cannot afford the transportation costs.

Acai is a perishable fruit that needs to be rapidly processed so as not to lose its quality. For this reason, the product is sold as soon as possible. Thus, the Acai is intended for middlemen who buy the product at the door of the producers and take them to the local market of the municipality.

In the harvest period, the average production per family is 822 rasas/harvest or 11.9 tons of Acai fruit. In the 2016 harvest, Acai was sold by the producers for R \$ 18.57/rasa. In the off-season, the volume produced was not quantified, since the production in this period is very scarce, so all fruit harvested is for the family consumption.

During the off-season, between January and June, about $28.8 \%$ of the community's farmers exercise other practices to contribute to family income, as shown in Table 3. Fishing was one of the activities that stood out in the family income, as well as the extraction of the palm heart of the trunks of the Acai plants that contribute in the monthly income of these families in the periods when Acai is scarce in the region.

Table 3. Other activities performed by farmers in the Acai off-season

\begin{tabular}{ll}
\hline Other economic activities & Percentage (\%) \\
\hline Only Acai crop & 71.2 \\
Fishing & 13.5 \\
Heart palm & 5.8 \\
Carpentry & 3.8 \\
Mechanics & 1.9 \\
Fishing and carpentry & 1.9 \\
Catering services & 1.9 \\
\hline
\end{tabular}

Although Acai berry is the most produced fruit most on the farms, the producers still cultivate other fruit trees in small scale and with low destination to the market, destining, roughly, these other fruits for the self-consumption. These crops make up the agroforestry yards that are close to the houses to facilitate family access since they are harvested according to their need or in the harvest period. Table 4 shows that coconut, cupuaçu, and lemon are produced by about $21.2 \%$ of the farmers, and cocoa (13.5\%), mango (9.6\%), banana (7.7\%) among others. 
In some communities in the Amazon, miriti (Mauritia flexuosa L.) is an important product that replaces the Acai in the diet of the dwellers in the offseason, because a "wine" can be also extracted from it and is consumed in the same way as the Acai, with manioc flour combined with the meals. According to Sousa (2018), the Riverside dwellers consume miriti in the winter when the fruit is more available, and the Acai is in the offseason, so, the producers chose mirit "wine" to make up their food base.

Native miriti areas also undergo a process of substitution due to intensified management of Acai. According to Santos et al. (2016), in a study carried out in a community in the municipality of Abaetetuba, in the state of Pará, as the demand for Acai has increased without the respective expansion in supply, the Acai price became more favorable than that of miriti fiber, which intensified its suppression, as well as of other native species. Thus, these species have been removed to give room for the intensification of Acai crop.

Table 4. Fruit cropped in the communities visited in Mamangal island, Igarapé-Miri municipality.

\begin{tabular}{lll}
\hline Cropped fruit & Frequency & Percentage (\%) \\
\hline Acai (Euterpe oleracea Mart.) & 52 & 100.0 \\
Coconut (Cocos nucifera L.) & 11 & 21.2 \\
Cupuacu (Theobroma grandiflorum) & 11 & 21.2 \\
Lemon (Citrus aurantifolia Swing) & 11 & 21.2 \\
Cocoa (Theobroma cacao L.) & 7 & 13.5 \\
Mango (Mangifera indica L.) & 5 & 9.6 \\
Banana (Musa spp.) & 4 & 7.7 \\
Miriti (Mauritia flexuosa L.) & 4 & 7.7 \\
Andiroba (Carapa guianensis Aubl.) & 3 & 5.8 \\
Guava (Psidium guajava L.) & 3 & 5.8 \\
Orange (Citrus sinensis L.) & 3 & 5.8 \\
Papaya (Carica papaya L.) & 3 & 5.8 \\
Pineapple (Ananas comosus L.) & 2 & 3.8 \\
Avocado (Persea americana Mill.) & 1 & 1.9 \\
Cashew (Anacardium occidentale L.) & 1 & 1.9 \\
Jambo (Syzygium malaccense L.) & 1 & 1.9 \\
Passion flower (Passiflora edulis Sims) & 1 & 1.9 \\
Tapereba (Spondias mombim L.) & 1 & 1.9 \\
Urucum (Bixa orellana L.) & 1 & 1.9 \\
\hline
\end{tabular}

\subsection{General Aspects of the Diet of the Residents in the Visited Communities}

Acai is the main food of the community because besides being present in most meals, it is consumed by all of the residents. It is usually consumed with cassava flour and tapioca, sugar and accompanied by salty foods like fish and shrimp. Respondents reported that they consume Acai every day, on average, twice a day. In addition, it was commented that Acai provides palatability to other foods, because according to several informants "when you do not have the Acai, food does not taste the same".

Table 5 shows the main sources of animal protein consumed by the interviewees. The most common dish is fish (for $78.8 \%$ of families), due to the ease of obtaining it by artisanal fishing. Beef is the second most consumed food (71.2\%), although access to this food is difficult because there are no butchers in the community. Chicken meat comes in third position (57.7\%), followed by shrimp (34.6\%) that are caught in the nearby rivers by the residents themselves and pork (7.7\%). With the arrival of electricity and acquisition of freezers, the inhabitants can buy meat in the city and store it. 
Table 5. Main sources of animal protein consumed by the residents of Mamangal community in the municipality of Igarapé-Miri

\begin{tabular}{ll}
\hline Most consumed animal protein & Percentage (\%) \\
\hline Fish & 78.8 \\
Meat & 71.2 \\
Chicken & 57.7 \\
Shrimp & 34.6 \\
Pork & 7.7 \\
\hline
\end{tabular}

\subsection{Rural Credit and Technical Assistance and Rural Extension (ATER)}

The main rural credit line acknowledged by the farmers is Programa Nacional de Fortalecimento da Agricultura Familiar (Pronaf)-National Program for Strengthening Family Farming. According to Nunes (2007), the target public of Pronaf are small family farmers who present certain characteristics such as use predominantly family labor, artisanal fishermen, small extractors and small fish farmers among other characteristics.

Regarding the credit provided by the government, $63.5 \%$ answered that they have the knowledge about it and $36.5 \%$ do not know it. However, $42.3 \%$ claim that they are benefited by Pronaf and $57.7 \%$ did not have access to it, showing that small farmers, for the most part, cannot or do not show interest in acquiring credit due to slowness and bureaucracy to be benefited.

Out of those who demand credit, $63.6 \%$ went to costing the management of the Acai area, that is, the credit was aimed at hiring labor for weed removal, thinning of the trunks and cleaning of the yard. On the other hand, $36.4 \%$ joined the credit to invest in a new Acai orchard or to renew the existing one. It should be emphasized, as remarked by Costa et al. (2016) on the importance of intensifying the supply of investment credit as a way to promote a positive effect on the modernization of the activity.

Credit was seen by the community as a great ally for maintaining and producing Acai. Out of the respondents benefiting from financing, $90.9 \%$ claimed that the credit improved the economic condition of families. Somewhat, credit helps in setting the man on the field, as well as helping them to have some competitiveness in the local market if the resource is applied to improve management techniques and even to move to more advanced systems of cultivation.

It was found that $50.0 \%$ of the respondents were able to pay the financing and $22.7 \%$ are still in the process of payment. Non-payment among these producers is of the order of $27.3 \%$. Producers still rated Pronaf as important for agriculture. A percentage of $63.6 \%$ stated that credit is good, that is, it is important for agriculture, especially for Acai management, while $18.2 \%$ rated it as good and fair. This result shows that credit is an instrument that contributes to promoting farming in the community since it provides improvements in the productive system through management. This finding coincides with the results of the study by Maciel et al. (2014), which was carried out in the municipality of Feijó, in the state of Acre, which identified the dynamics of the Acai production system, by increasing the production and income of the producers and also contributed to promote local development.

The lack of technical assistance in the community is still an issue to be controlled. Out of those interviewed, $78.8 \%$ reported that they did not receive any technical assistance nor that it did meet their needs. Difficulties in accessing technical assistance are still a reality in the community due to the obstacles that public ATER encounters with the small contingent of available professionals and problems with the means to make the trips for the technical visits. During the field surveys, it was reported that the vessel of the local office of the official technical assistance and rural extension service in the state of Pará, which serves the islands of the municipality of Igarapé-Miri, was damaged and unable to provide the visits to the producers.

\section{Final Considerations}

Acai is one of the main products in the diet the Riverside dwellers, being also the main source of income in the communities of the island of Mamangal, in the municipality of Igarapé-Miri (PA). As the demand for Acai has increased, the producers of these communities have managed to generate an income that has raised their standard of living, observed in the expansion of the consumption of durable goods and in the improvements in their households, although serious problems of infrastructure persist, eventually influencing the quality of life and the environmental issue. 
The communities visited in this study need to overcome the strong financial dependence on the income provided by the Acai, especially for the off-season period, in order to ensure environmental and economic sustainability. Likewise, this issue must be addressed by the agricultural policymakers in the Amazon, because it cannot be conceived that the expansion of the Acai supply can be assured based on extractivism or management. The volume that the market currently requires needs a scale and another production system. One should be aware that the history of the rubber cycle debacle, due to non-compliance with supply on a rational basis and that led to planting in another part of the world, can be repeated with the Acai case, affecting the communities and the regional economy.

The production of these traditional communities, therefore, must ensure the food security for their members and, at the same time, generate surpluses for short circuits of the economy, that is, to meet the demand of its surroundings, as a way of guaranteeing a source of income for the autonomy of the communities and the balance between environmental and economic sustainability.

\section{References}

Cavalcante, P. B. (2010). Frutas comestiveis na Amazônia. Belém: MPEG.

Celuppi, M. C., Meirelles, C. R. M., \& Cymrot, R. (2017). Habitação ribeirinha no Amazonas: O conforto por meio do design de componentes e de estratégias bioclimáticas. Fórum Habitar, Belo Horizonte, MG.

Costa, J. F., Santos, M. A. S., Rebello, F. K., Costa, A. D., \& Silva, J. S. (2016). A política de crédito rural e os financiamentos à cultura da mandioca no estado do Pará, 1990-2012. Revista Raízes e Amidos Tropicais, 12(1), 1-14. https://doi.org/10.17766/1808-981X.2016v12n1p1-14

Costa, M. R. T. R., Homma, A. K. O., Rebello, F. K., Souza Filho, A. P.S., Fernandes, G. L. C., \& Baleixe, W. (2017). Atividade Agropecuária no estado do Pará (Documentos 432). Belém: Embrapa Amazônia Oriental. Retrieved from https://www.embrapa.br/busca-de-publicacoes/-/publicacao/1073940/atividade-agropecuari a-no-estado-do-para

Homma, A. K. O. (2014). Extrativismo vegetal na Amazônia: História, ecologia, economia e domesticação. Brasília: Embrapa.

IBGE (Instituto Brasileiro de Geografia e Estatística). (2018a). Cidades. Retrieved from https://cidades.ibge. gov.br/brasil/pa/igarape-miri/panorama

IBGE (Instituto Brasileiro de Geografia e Estatística). (2018b). Levantamento sistemático da produção agrícola. Retrieved from https://sidra.ibge.gov.br/tabela/289

INCRA (Instituto Nacional de Colonização e Reforma Agrária). (2006). Levantamento de dados e informações da Ilha Mamangal: Estudo de viabilidade para implantação Agroextrativista (PAE), considerando aspectos técnicos, sócios-econômicos e ambientais. Belém: INCRA.

Maciel, R. C. G., Penha, D. de L. B., Cavalcante Filho, P. G., Souza, D. L de, Silva, P. A. da, \& Santos, F. S. L. dos. (2014). Desenvolvimento rural, agricultura familiar e os produtos florestais não madeireiros: o caso do açaí na região de Feijó, Estado do Acre. Rev. de Economia Agrícola, 61(1), 5-21.

Nogueira, L. R. B. (2016). Arquitetura vernacular e paisagem amazônica: Um caminho na busca pelo habitar poético. Revista da Abordagem Gestáltica-Phenomenological Studie, XXII(2), 171-180.

Nogueira, O. L., \& Homma, A. K. O. (1998). Análise econômica de sistemas de manejo de açaizais nativos no estuário amazônico. Belém: Embrapa.

Nunes, S. P. (2007). Instrumentos de política agrícola para a agricultura e a agricultura familiar no Brasil. Departamento de estudos Socioeconômicos Rurais, Boletim Eletrônico.

Rebello, F. K. (1992). O açaizeiro: alimento básico ou palmito? Um estudo de caso no município do Acará (PA). Curso Internacional de Formação de Especialistas em Desenvolvimento de Áreas Amazônicas. Núcleo de Altos Estudos da Amazônia. Belém: NAEA.

Rebello, F. K., \& Homma, A. K. O. (2017). História da colonização do Nordeste Paraense: Uma reflexão para o futuro da Amazônia. Belém: Edufra.

Rodrigues, P. L., Guimarães, J. B., Martins, C. M., Santos, M. A. S., \& Rebello, F. K. (2017). Dinâmica socioeconômica e organizacional em comunidade remanescente do quilombo Rio Gurupá, Marajó, Pará. Revista Verde de Agroecologia e Desenvolvimento Sustentável, 12(1), 105-116. https://doi.org/10.18378/ rvads.v12i1.4344 
Santos, P. C. dos, Santos, A. V. F. dos, Rebello, F. K., Silva Junior, J. I. de S., \& Barbosa, M. F. (2016). Açaí e fibra de miriti como bens substitutos na oferta dos agroextrativistas do municipio de Abaetetuba (PA). Anais do XIII Seminário de Integração da UFRA.

Schauss, A. G., Wu, X., Prior, R. L., Ou, B., Patel, D., Huang, D., \& Kababick, J. P. (2006). Phytochemical and nutrient composition of the freeze-dried Amazonian palm berry, Euterpe oleraceae mart. (acai). J Agric Food Chem, 54, 8598-8603. https://doi.org/10.1021/jf060976g

Sousa, F. F., Vieira-da-Silva, C., \& Barros, F. B. (2018). The (in)visible market of miriti (Mauritia flexuosa L. f.) fruits, the winter Acai, in Amazonian riverine communities of Abaetetuba, Northern Brazil. Global Ecology and Conservation, 14, e00393. https://doi.org/10.1016/j.gecco.2018.e00393

Tagore, M. de P. B., Canto, O. do, \& Sobrinho, M. V. (2018). Políticas públicas e riscos ambientais em áreas de várzea na Amazônia: O caso do PRONAF para produção do açaí. Desenvolv. Meio Ambiente, 45, $194-214$. https://doi.org/10.5380/dma.v45i0.51585

Udani, J. K., Singh, B. B., Singh, V. J., \& Barrett, M. L. (2011). Effects of Açai (Euterpe oleracea Mart.) berry preparation on metabolic parameters in a healthy overweight population: A pilot study. Nutrition Journal. https://doi.org/10.1186/1475-2891-10-45

\section{Notes}

Note 1. In order to have a quick idea of the cultural and socioeconomic importance of the Acai for communities of the Amazon, especially in the state of Pará, the area with the highest occurrence of native Acai areas, for example, the consecrated song "Sabor Açaí" by the Pará composers Nilson Chaves and João Gomes (And that you were planted/and that you were planted/to invade our table/and to make our house wealthy.../you are the plant that feeds the passion of our people.../saint fruit martyr fruit/you have the gift of beings where many have nothing/ones call you Acai tree...). Another good example is the sensitivity expressed in the song "Acai", by the renowned composer from Alagoas, Djavan who emphasizes in its letter the function of this fruit as guardian of food security of a significant portion of the inhabitants of the northern region of Brazil.

Note 2. They are small wicker baskets or handcrafted baskets made from Arumã (Ischnosiphon ovatus), used by the farmers in the region as a common measure for the commercialization of the Acai fruit. There are two sizes of wicker baskets: small (14.5 kg fruit $+0.5 \mathrm{~kg}$ wicker bascket), which corresponds to a can; and, the large (28 $\mathrm{kg}$ fruit $+1 \mathrm{~kg}$ of wicker basket). Currently, the $30 \mathrm{~kg}$ plastic bowl (bascket) (28 $\mathrm{kg}$ fruit and $2 \mathrm{~kg}$ of bowl) is also used because of the practicality on the cleaning of the utensil.

\section{Copyrights}

Copyright for this article is retained by the author(s), with first publication rights granted to the journal.

This is an open-access article distributed under the terms and conditions of the Creative Commons Attribution license (http://creativecommons.org/licenses/by/4.0/). 